\title{
Phylogenetic and morphological appraisal of Diatrype lijiangensis sp. nov. (Diatrypaceae, Xylariales) from China
}

\author{
Thiyagaraja $V^{1,2,3,5}$, Senanayake $I^{2,3,4}$, Wanasinghe $D^{2,3,5}$, Karunarathna \\ $\mathrm{SC}^{2,3,5}$, Worthy $\mathrm{FR}^{3,6}$, To-Anun $\mathrm{C}^{{ }^{*}}$
}

\author{
${ }^{1}$ Department of Biology, Faculty of Agriculture, Chiang Mai University, Chiang Mai 50002, Thailand \\ ${ }^{2}$ Centre of Excellence in Fungal Research, Mae Fah Luang University, Chiang Rai 57100, Thailand \\ ${ }^{3}$ Key Laboratory for Plant Biodiversity and Biogeography of East Asia (KLPB), Kunming Institute of Botany, Chinese \\ Academy of Science, Kunming 650201, Yunnan, People's Republic of China \\ ${ }^{4}$ Shenzhen Key Laboratory of Microbial Genetic Engineering, College of Life Science and Oceanography, Shenzhen \\ University, 3688, Nanhai Avenue, Nanshan, Shenzhen 518055, China \\ ${ }^{5}$ World Agro forestry Centre East and Central Asia, Kunming 650201, Yunnan, People's Republic of China \\ ${ }^{6}$ Centre for Mountain Futures, Kunming Institute of Botany, Kunming 650201, Yunnan, People's Republic of China
}

Thiyagaraja V, Senanayake IC, Wanasinghe DN, Karunarathna SC, Worthy FR, To-Anun C 2019 Phylogenetic and morphological appraisal of Diatrype lijiangensis sp. nov. (Diatrypaceae, Xylariales) from China. Asian Journal of Mycology 2(1), 198-208, Doi 10.5943/ajom/2/1/10

\begin{abstract}
The majority of Diatrype species are saprobes, while a few species are pathogens which form cankers on forest trees. The placement of several species in the genus Diatrype is uncertain, as the phylogeny has yet to be well-resolved with extensive taxon sampling and authentic ex-type cultures. In this study, a diatrype-like taxon was found on decaying wood in Lijiang, Yunnan Province, China. Morphological characteristics and phylogenetic analyses of combined ITS and $\beta$ tubulin sequences, supported the conclusion that the taxon is a new species, which is named as Diatrype lijiangensis. The new species differs from other species of Diatrype in asci and ascospore characteristics. The morphological similarities and dissimilarities of the new species with phylogenetically close alliances are discussed. Micro-morphological characteristics of this novel taxon are illustrated with descriptions.
\end{abstract}

Key words - 1 new species - Phylogeny - Sordariomycetes - Taxonomy

\section{Introduction}

Diatrypaceae Nitschke, a family in Xylariales, comprises 17 genera (Index Fungorum 2019) with Diatrype Fr. as the type genus (Maharachchikumbura et al. 2015, 2016, Senanayake et al. 2015, de Almeida et al. 2016, Dayarathne et al. 2016, Mehrabi et al. 2016, Senwanna et al. 2017, Shang et al. 2017, Wijayawardene et al. 2018). Species of Diatrypaceae are mostly saprobes on decaying wood (Carter 1991, Acero et al. 2004, Trouillas \& Gubler. 2004, Mehrabi et al 2015, de Almeida et al. 2016, Shang et al. 2017), however several species are pathogens and endophytes (Acero et al. 2004, de Errasti et al. 2014, Shang et al. 2017). The taxa of Diatrypaceae have perithecial ascomata, a poor or well-developed stroma with an ostiole, short to long neck, clavate or spindle-shaped asci and allantoid ascospores (Trouillas et al. 2010, Mehrabi et al. 2015, Dayarathne et al. 2016, de Almeida et al. 2016, Senwanna et al. 2017, Shang et al. 2017). However, the intraspecific variations in stromatal characteristics make the delineation of the genera in 
Diatrypaceae challenging (Vasilyeva \& Stephenson 2004, Dayarathne et al. 2016). Asexual morphs have been reported to be either coelomycetous, ex: Cytosporina Sacc and Libertella Desm. (de Almeida et al. 2016, Senwanna et al. 2017, Shang et al. 2017) or hypomycetous, ex: genus Phaeoisaria which has recently been linked to the family Pleurotheciaceae (Luo et al. 2018). The asexual morph has not been used to identify species in Diatrypaceae (de Almeida et al. 2016, Senwanna et al. 2017).

Recent studies have provided updated phylogenetic analyses of Diatrypaceae (Mehrabi et al. 2015, Dayarathne et al. 2016, de Almeida et al. 2016, Mehrabi et al. 2016, Senwanna et al. 2017, Shang et al. 2017). However, phylogenetic placement of Eutypa, Diatrype and Diatrypella in this family remains unresolved (de Almeida et al. 2016, Senwanna et al. 2017, Shang et al. 2017). Therefore, more taxon sampling and extended molecular data are needed to elucidate their natural placements and close alliances (Shang et al. 2017).

In this study, morphological characteristics and molecular phylogenetic analyses showed that the new fungus groups within Diatrype and forms a strongly supported clade. The objectives of this study are to 1) introduce a new species of Diatrype and 2) strengthen its taxonomic placement using both morphological characteristics and phylogenetic analyses results of maximum likelihood and Bayesian analyses, based on combined ITS and $\beta$-tubulin sequences.

\section{Material and Methods}

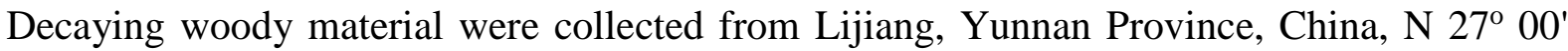
30.8", E $100^{\circ} 11^{\prime} 26.1^{\prime \prime}, 3234 \mathrm{~m}$ in September 2018 and brought to the laboratory in a Zip-lock plastic bag. Samples were examined under a Motic SMZ 168 Series microscope and photographed using a Carl Zeiss Discovery V8 stereo-microscope fitted with Axiocam. Hand sections of the ascomata, were mounted on $5 \% \mathrm{KOH}$. Sections of ascomata and other micro-morphological characteristics were photographed using a Nikon ECLIPSE 80i compound microscope fitted with a Canon 550D digital camera. All microscopic measurements were made with Tarosoft Image Frame Work (v.0.9.0.7).

Images used for figures were processed with Adobe Photoshop CS3 Extended version 10.0 software (Adobe Systems, USA). The holotype specimen was deposited in the Mae Fah Luang University (MFLU) Herbarium, Chiang Rai, Thailand. Faces of Fungi and Index Fungorum numbers were provided as outlined in Jayasiri et al. (2015) and Index Fungorum (2019) respectively. The new species was established based on the recommendations of Jeewon \& Hyde (2016). We could not obtain a pure culture of this fungus and all the morphological characteristics and phylogenetic data were obtained from fresh fruiting structures.

\section{DNA extraction, PCR amplification and gene sequencing}

DNA was extracted directly from fruiting bodies of the fungus as outlined by Wanasinghe et al. (2018). An E.Z.N.A. ® Forensic DAT (D3591 - 01, Omega Bio - Tek) DNA extraction kit was used to extract DNA by following the manufacturer's instructions. DNA samples that were intended for use as a template for PCR were stored at $4^{\circ} \mathrm{C}$ for use in regular work and duplicated at $-20{ }^{\circ} \mathrm{C}$ for long-term storage. DNA sequence data were obtained from internal transcribed spacers (ITS) and $\beta$-tubulin. The internal transcribed spacers (ITS) were amplified with primers ITS4 and ITS5 (White et al. 1990) while the $\beta$-tubulin was amplified with primers Bt2a and Bt2b (Glass \& Donaldson 1995).

The components for the PCR amplification are described below. The final volume of the PCR mixture was $25 \mu \mathrm{l}$ with $2.0 \mu \mathrm{l}$ of DNA template, $1 \mu \mathrm{l}$ of each forward and reverse primers, $12.5 \mu \mathrm{l}$ of $2 \times$ Easy Taq PCR Super Mix (mixture of Easy Taq TM DNA Polymerase, dNTPs, obtained buffer (Beijing Trans Gen Biotech Co., Chaoyang District, Beijing, PR China) and $8.5 \mu$ l sterilized water. The PCR thermal cycle program for ITS gene was used as: initial denaturation at $94^{\circ} \mathrm{C}$ for 3 mins, followed by 35 cycles of $30 \mathrm{sec}$ at $94^{\circ} \mathrm{C}, 50 \mathrm{sec}$ at $55^{\circ} \mathrm{C}$, and $1 \mathrm{~min}$ at $72^{\circ} \mathrm{C}$, with a final extension of $10 \mathrm{mins}$ at $72^{\circ} \mathrm{C}$. Amplification of $\beta$-tubulin was accomplished by an initial denaturation at $94^{\circ} \mathrm{C}$ for 3 mins, followed by 35 cycles consisted of denaturation at $94^{\circ} \mathrm{C}$ for $30 \mathrm{sec}$, 
annealing at $55^{\circ} \mathrm{C}$ for $50 \mathrm{sec}$, elongation at $72^{\circ} \mathrm{C}$ for $1 \mathrm{~min}$ with a final extension for $10 \mathrm{mins}$ at $72^{\circ} \mathrm{C}$.

PCR products were observed on $1 \%$ agarose electrophoresis gels stained with ethidium bromide. Purification and DNA sequencing were performed by Shanghai Sangon Biological Engineering Technology \& Services Co. (Shanghai, P.R. China). The nucleotide sequence data acquired were deposited in GenBank and alignments and the trees were submitted to TreeBASE under submission ID 24320.

\section{Phylogenetic analyses and species recognition}

Sequence homologies were searched by using the NCBI BLAST search engine for the preliminary identification (https://www.ncbi.nlm.nih.gov). Phylogenetic analyses were constructed based on ITS and $\beta$-tubulin sequence data. Sequences of available closely related taxa from the family Diatrypaceae were obtained from GenBank and following Senwanna et al. (2017) (Table 1). Kretzschmaria deusta (CBS 826.72) and Xylaria hypoxylon (CBS 122620) were selected as the outgroup taxa. Multiple sequence alignments were generated with MAFFT v. 7 (http://mafft.cbrc.jp/alignment/server/index.html; Katoh et al. 2017), and where necessary were manually adjusted using Bioedit v. 7.0.5.2 (Hall 1999).

Table 1 Taxa used in the phylogenetic analyses and their GenBank accession numbers. The newly generated sequence from this study, and the ex-type isolates are given in bold.

\begin{tabular}{|c|c|c|c|}
\hline \multirow{2}{*}{ Taxon } & \multirow{2}{*}{ Strain } & \multicolumn{2}{|c|}{ GenBank Accessions } \\
\hline & & ITS & $\beta$-tubulin \\
\hline Allocryptovalsa polyspora & MFLU:17-1218 & NR153588 & - \\
\hline Allocryptovalsa rabenhorstii & WA07CO & HQ692620 & HQ692522 \\
\hline Allocryptovalsa rabenhorstii & WA08CB & HQ692619 & HQ692523 \\
\hline Anthostoma decipiens & IPVFW349 & АM399021 & AM920693 \\
\hline Anthostoma decipiens & JL567 & JN975370 & JN975407 \\
\hline Cryptosphaeria ligniota & CBS 273.87 & KT425233 & MF359667 \\
\hline Cryptosphaeria pullmanensis & HBPF24 & KT425202 & GQ294014 \\
\hline Cryptosphaeria pullmanensis & ATCC 52655 & KT425235 & KT425170 \\
\hline Cryptosphaeria subcutanea & DSUB100A & KT425189 & KT425124 \\
\hline Cryptosphaeria subcutanea & CBS 240.87 & KT425232 & KT425167 \\
\hline Cryptovalsa ampelina & A001 & GQ293901 & GQ293972 \\
\hline Cryptovalsa ampelina & DRO101 & GQ293902 & GQ293982 \\
\hline Diatrype bullata & UCDDCh400 & DQ006946 & DQ007002 \\
\hline Diatrype disciformis & MFLUCC 15-0538 & KRO92795 & - \\
\hline Diatrype disciformis & CBS 205.87 & AJ302437 & - \\
\hline Diatrype lijiangensis & MFLU:19-0717 & MK852582 & MK852583 \\
\hline Diatrype spilomea & D17C & AJ302433 & - \\
\hline Diatrype stigma & DCASH200 & GQ293947 & GQ294003 \\
\hline Diatrype undulata & D20C & AJ302436 & - \\
\hline Diatrype virescens & 1057 & KU320619 & _- \\
\hline Diatrypella frostii & UFMGCB 1917 & HQ377280 & - \\
\hline Diatrypella heveae & MFLU:17-1216 & NR154046 & HQ692502 \\
\hline Diatrypella major & Isolate 1058 & KU320613 & - \\
\hline Diatrypella tectonae & MFLUCC 12-0172a & KY283084 & - \\
\hline Diatrypella tectonae & MFLUCC 12-0172b & KY283085 & KY421043 \\
\hline Diatrypella verruciformis & UCROK1467 & JX144793 & JX174093 \\
\hline Diatrypella verruciformis & UCROK754 & JX144783 & JX174083 \\
\hline Diatrypella vulgaris & HVGRF03 & HQ692590 & HQ692502 \\
\hline Eutypa armeniacae & ATCC 28120 & DQ006948 & DQ006975 \\
\hline Eutypa guttulata & HUEFS 192075 & AJ302450 & - \\
\hline Eutypa lata & EP18 & HQ692611 & HQ692501 \\
\hline Eutypa lata & RGA01 & HQ692614 & HQ692497 \\
\hline Eutypella citricola & HVVIT07 & HQ692579 & HQ692512 \\
\hline Eutypella citricola & HVGRF01 & HQ692589 & HQ692521 \\
\hline Eutypella vitis & UCD2428TX & FJ790851 & GU294726 \\
\hline
\end{tabular}


Table 1 Continued.

\begin{tabular}{llll}
\hline \multirow{2}{*}{ Taxon } & \multirow{2}{*}{ Strain } & \multicolumn{2}{l}{ GenBank Accessions } \\
\cline { 3 - 4 } & ITS & -tubulin \\
\hline Eutypella vitis & UCD2291AR & HQ288224 & HQ288303 \\
Halodiatrype avcenniae & MFLUCC 15-0953 & KX573916 & KX573931 \\
Kretzschmaria deusta & MFLUCC 15-1277 & KX573915 & KX573932 \\
Monosporascus cannonballus & CBS 826.72 & KU683767 & KU684190 \\
Monosporascus cannonballus & CMM3646 & JX971617 & - \\
Peroneutypa alsophila & ATCC 26931 & NR111370 & - \\
Peroneutypa comosa & EL58C & AJ302467 & - \\
Peroneutypa diminutispora & BAFC 393 & KF964568 & \\
Peroneutypa kochiana & MFLUCC 17-2144 & MG873479 & MH316765 \\
Peroneutypa rubiformis & EL53M & AJ302462 & - \\
Peroneutypa scoparia & MFLUCC 17-2142 & MG873477 & - \\
Quaternaria quaternata & MFLUCC 11-0478 & KU940151 & - \\
Quaternaria quaternata & GNF13 & KR605645 & - \\
Xylaria hypoxylon & CBS 278.87 & AJ302469 & - \\
\hline
\end{tabular}

Phylogenetic analyses of both individual and combined aligned data were performed under maximum-likelihood (ML) and Bayesian (BI) criteria. Terminal ends of sequences and ambiguous regions were deleted manually and excluded from the dataset. The phylogeny web tool "ALTER" (Glez-Peña et al. 2010) was used to convert sequence alignment from FASTA to PHYLIP for RAxML analysis and FASTA to NEXUS format for Bayesian analysis. The estimated model of maximum likelihood and Bayesian analyses were performed independently for each locus using MrModeltest v.2.2 (Nylander 2004). Maximum likelihood trees were generated using RAxMLHPC2 on XSEDE (8.2.8) (Stamatakis 2006, Stamatakis et al. 2008) in the CIPRES Science Gateway platform (Miller et al. 2010).

MrBayes v. 3.0b4 was used to perform Bayesian analysis (Ronquist \& Huelsenbeck 2003). GTR + GAMMA + I nucleotide substitution best-fit model is determined with MrModeltest v. 2.2 (Nylander 2004). The Bayesian Markov Chain Monte Carlo (BMCMC) sampling method in MrBayes v. 3.0b4 (Huelsenbeck \& Ronguist 2001) was used to define Bayesian Posterior Probabilities (BP) (Rannala et al. 1998, Zhaxybayeva \& Gogarten 2002). Six simultaneous Markov Chains were run for 5 million generations and the trees were sampled every $100^{\text {th }}$ generation. The first $10 \%$ of trees that represented the burn-in phase were discarded, and only the remaining $90 \%$ of trees were used for calculating posterior probabilities (PP) in the majority rule consensus tree. The resulting trees are displayed using FigTree v1.4.0 (Rambaut 2012) and copied to Microsoft PowerPoint 2013 and converted to jpeg file in Adobe Photoshop CS6 version 13.0. (Adobe Systems. U.S.A.).

\section{Results}

\section{Phylogenetic analyses}

Our preliminary dataset comprised representatives of the family Diatrypaceae and our strain nested together with Diatrype sensu stricto based on combined ITS and $\beta$-tubulin data. We excluded other Diatrype species which were not cladded in Diatrype sensu stricto from the final analysis (Fig. 1). Based on megablast search of the NCBI nucleotide database using the ITS sequence, the highest similarities were found with $D$. spilomea $[$ GenBank AJ302433; Identities = 587/600 (97\%), Gaps = 75/600 (12\%)], D. stigma [GenBank KX828152; Identities = 517/600 $(97 \%)$, Gaps $=87 / 600(14 \%)$ ] and D. virescens [GenBank MH864890; Identities = 584/607 (96\%), (Gaps $=7 / 607(2 \%)$. Based on megablast search of the NCBI nucleotide database using the $\beta$ tubulin sequence, the highest similarities were found with undefined Diatrype species. The results obtained by both ML and BI analyses of the combined ITS and $\beta$-tubulin dataset comprised selected 50 taxa including the new strain. 
Phylogenetic analyses obtained from maximum likelihood and Bayesian inference analysis showed similar topologies and were not significantly different. The best scoring RAxML tree was selected to represent the relationship analyses obtained among taxa, with the final ML optimization likelihood value of -8747.484409 and is shown in Fig. 1. Bayesian posterior probabilities from MCMC were evaluated with final average standard deviation of split frequencies $=0.006514$. The new strain, MFLU 19-0717, was grouped in Diatrype sensu sticto within Diatrypaceae and formed a distinct clade $(\mathrm{ML} / \mathrm{BP}=97 / 1.00)$ with high bootstrap support (Fig. 1). Diatrype sensu sticto comprises $D$. stigma, $D$. undulate and $D$. bullata and $D$. spilomea species with the type $D$. disciformis and this concur the phylogenetic studies of Dayarathne et al. 2016, de Almeida et al. 2016, Senwanna et al. 2017, Shang et al. 2017. We have defined Diatrype sensu sticto based on the published sequence data from reference stain of the type species $D$. disciformis (Senanayake et al. 2015).

\section{Taxonomy}

Diatrype lijiangensis Thiyagaraja \& Wanas., sp. nov.

Index Fungorum Number: IF556377; Facesoffungi number: FoF06032

Etymology - The specific epithet "lijiangensis" refers to the name of the place, from which the type specimen of the species was collected.

Holotype - MFLU 19-0717

Saprobic on decaying woody bark. Sexual morph: Ascostromata $1 \mathrm{~mm}$ diam., black, superficial, solitary to gregarious, subglobose or ellipsoidal, carbonaceous. Ascomata 170-460 $\times$ 200-300 $\mu \mathrm{m}(\overline{\mathrm{x}}=300 \times 250 \mu \mathrm{m}, \mathrm{n}=10)$, perithecial, black, subglobose to ovoid, clustered, immersed in ascostroma, glabrous, 2-5 loculate, ostiolate. Ostiole papillate or apapillate, central, ostiolar canal filled with periphyses. Peridium 15-25 $\mu \mathrm{m}$ wide, composed of two layers, outer layer comprising several layers of thick-walled, dark brown to black cells of textura angularis, inner layer comprising 3-5 layers of thin-walled, hyaline cells of textura angularis. Hamathecium 140$165 \mu \mathrm{m}$ wide, hyaline. Paraphyses $2-4 \mu \mathrm{m}$ wide, arising from base of perithecia, composed of long, narrow, unbranched, septate, guttulate, narrowing and tapering towards the apex, with apex blunt. Asci 50-90 × 6-9 $\mu \mathrm{m}(\overline{\mathrm{x}}=65 \times 8 \mu \mathrm{m}, \mathrm{n}=20), 8$-spored, unitunicate, thin-walled, clavate to cylindric clavate, long pedicillate, apically truncate. Ascospores 6-8 $\times 1-2 \mu \mathrm{m}(\overline{\mathrm{x}}=7 \times 1.5 \mu \mathrm{m}, \mathrm{n}=$ 30), overlapping bi-seriate, allantoid, aseptate, hyaline to pale-brown, with one to few small guttules, slightly to moderately curved and smooth-walled. Asexual morph: Undetermined.

Material examined - China, Yunnan Province, Lijiang, on dead wood of unidentified host, N $27^{\circ}$ 00' 30.8", E $100^{\circ} 11^{\prime}$ 26.1", 3234m, 7 September 2018, V. Thiyagaraja (MFLU 19-0717, holotype).

Addition GenBank number - LSU (MK810546)

\section{Discussion}

The genus Diatrype was introduced by Fries (1849) with the type species $D$. disciformis (Hoffm.) (Tilak 1964). It comprises 60 species (Wijayawardene et al. 2017), of which the majority are saprobes, with a few species that are pathogens which form cankers on forest trees. Its asexual morph is reported as libertella-like (Senanayake et al. 2015, Dayarathne et al. 2016, Wijayawardene et al. 2017). The species of Diatrype possess characteristics that include perithecia embedded in discoid or widely effuse stromata that are erumpent from the bark (Vasilyeva \& Stephenson. 2009). The young stromata are sometimes covered with a layer of sterile tissue that eventually peels off to expose a fertile surface extruded with papillate or stellate ostioles (Vasilyeva \& Stephenson. 2009, Dayarathne et al. 2016). The polysporous ascus feature has been traditionally used to distinguish the species of Diatrype from those of Diatrypella (Liu et al. 2015).

The most recent phylogenetic analysis for the genera of Diatrypaceae is provided by Senwanna et al. (2017) with twelve genera. The genera Diatrype, Diatrypella and Eutypa are polyphyletic within the family as found in several previous studies (Acero et al. 2004, Trouillas et 
al. 2011, Mehrabi et al. 2015, 2016, de Almeida et al. 2016, Senwanna et al. 2017, Shang et al. 2017). In this study, we introduce a new species to the family Diatrypaceae based on molecular phylogenetic analyses of combined ITS and $\beta$-tubulin sequence data and morphological characteristics. According to our phylogenetic analyses, the genus Diatrype sensu stricto formed a district clade (ML/BP=97/1.00) with selected taxa including D. disciformis, $D$. stigma, D. undulate, $D$. virescens, $D$. bullata, $D$. spilomea, and our new species $D$. lijiangensis. However, further studies need to clarify the taxonomic placement of these taxa.

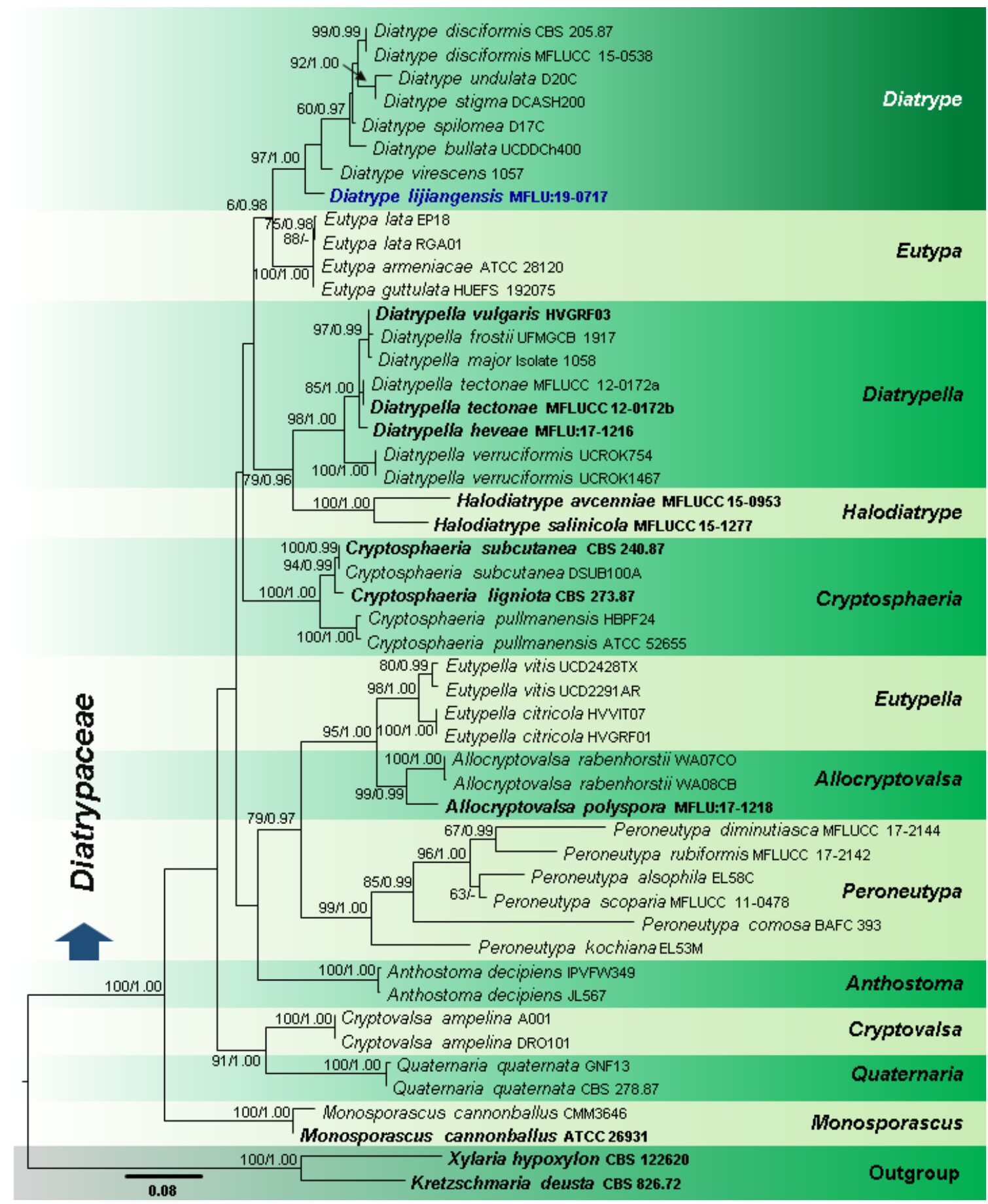

Fig. 1 - RAxML tree based on analysis of combined ITS and $\beta$-tubulin partial sequence data. Bootstrap support values for ML equal or greater than 60\%, and Bayesian posterior probabilities (BP) equal or greater than 0.90 are given as ML/BP above the nodes. The tree is rooted to Kretzschmaria deusta (CBS 826.72) and Xylaria hypoxylon (CBS 122620). All ex-type strains are displayed in bold and the new species that was found in this study is displayed in blue bold. 
Our novel taxon $D$. lijiangensis exhibits distinct morphological characteristics: viz. long pedicellate asci $(50-90 \mu \mathrm{m}$ ) with superficial stromata (Fig. 2) which contrast to those recorded for D. acericola $(23-27 \mu \mathrm{m})$, D. albopruinosa $(40-60 \mu \mathrm{m})$, D. bullata $(25-30 \mu \mathrm{m})$, D. hypoxyloides $(50-90 \mu \mathrm{m})$, D. macounii $(25-30 \mu \mathrm{m})$ D. stigma $(25-30 \mu \mathrm{m})$ and D. subundulata $(35-40 \mu \mathrm{m})$ which were previously collected from China (Vasilyeva \& Ma 2014) (Table 2).

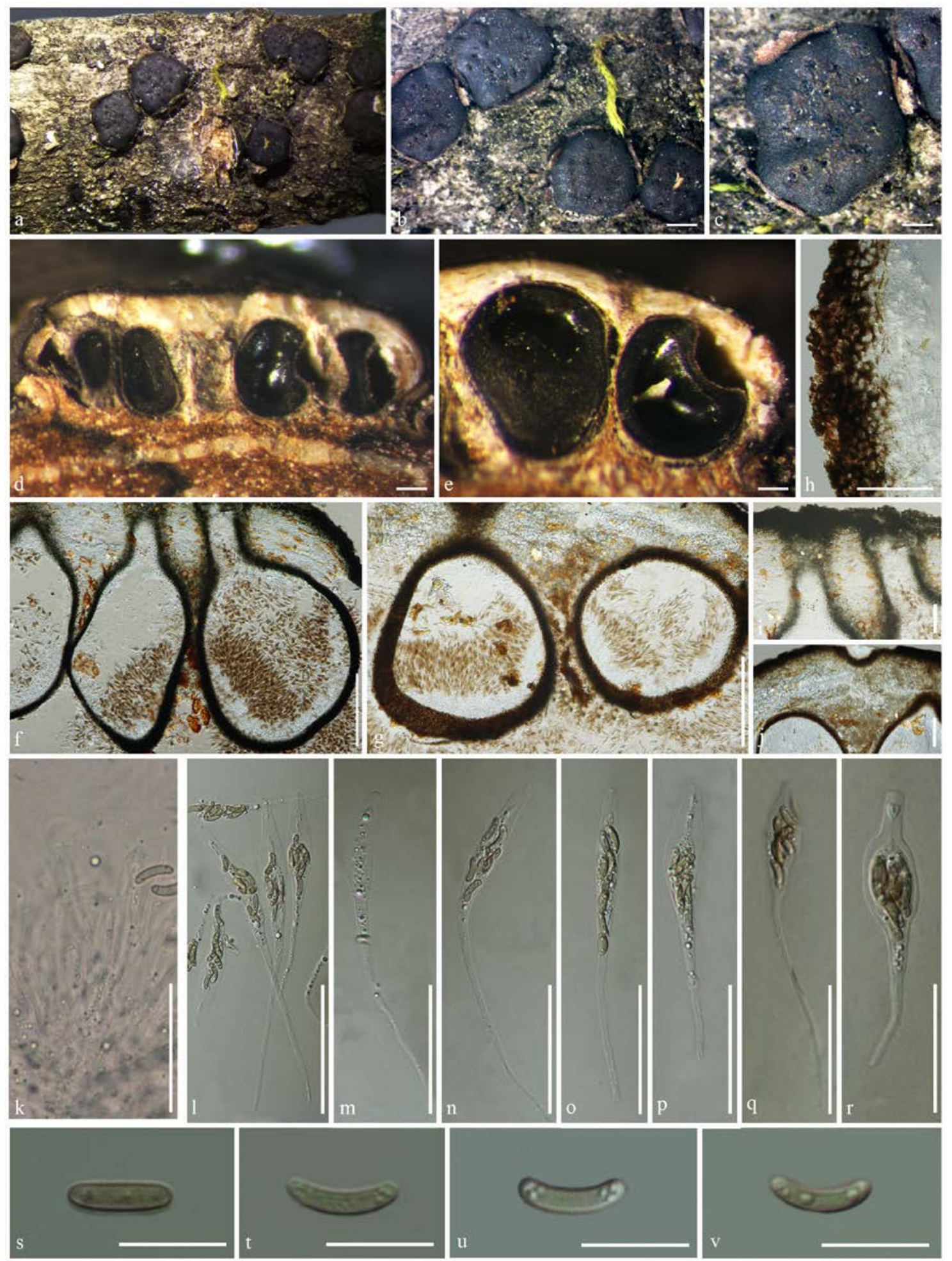

Fig. 2 - Diatrype lijiangensis (MFLU 19-0717, holotype). a-c Stromata on substrate. d, e Crosssection of stroma. f, g Vertical section through stroma showing ostioles and perithecia. h Peridium. i, j Ostiolar canals. k Paraphyses. l-r Asci. r-u Ascospores. Scale bars: b-e $=200 \mu \mathrm{m}, \mathrm{f}, \mathrm{g}=100 \mu \mathrm{m}$, $\mathrm{h}=30 \mu \mathrm{m}, \mathrm{k}-\mathrm{r}=20 \mu \mathrm{m}, \mathrm{s}-\mathrm{v}=5 \mu \mathrm{m}$ 
Table 2 Synopsis of $D$. lijiangensis and related species discussed in this study

\begin{tabular}{|c|c|c|c|c|c|c|c|}
\hline Species name & $\begin{array}{l}\text { Colour of } \\
\text { entostroma }\end{array}$ & $\begin{array}{l}\text { Ascus } \\
\text { length } \\
(\mu \mathrm{m})\end{array}$ & $\begin{array}{l}\text { Ascus } \\
\text { width } \\
(\mu \mathrm{m})\end{array}$ & $\begin{array}{l}\text { Ascospore } \\
\text { color }\end{array}$ & $\begin{array}{l}\text { Ascospore } \\
\text { length } \\
(\mu \mathrm{m})\end{array}$ & $\begin{array}{l}\text { Ascospore } \\
\text { width } \\
(\mu \mathrm{m}) \\
\end{array}$ & Reference \\
\hline D. lijiangensis & Dark brown & $50-90$ & $6-9$ & $\begin{array}{l}\text { Hyaline to } \\
\text { pale-brown }\end{array}$ & $6-8$ & $1-2$ & This study \\
\hline D. acericola & $\begin{array}{l}\text { Brownish or } \\
\text { almost black }\end{array}$ & $23-27$ & $5-7$ & $\begin{array}{l}\text { Very slightly } \\
\text { yellowish }\end{array}$ & $7.5-9$ & $0.9-1.1$ & $\begin{array}{l}\text { Vasilyeva \& Ma } \\
2014\end{array}$ \\
\hline $\begin{array}{l}\text { D. } \\
\text { albopruinosa }\end{array}$ & $\begin{array}{l}\text { Brownish or } \\
\text { almost black }\end{array}$ & $40-60$ & $10-15$ & Brownish & $\begin{array}{l}12-15(- \\
18)\end{array}$ & $3.5-4$ & $\begin{array}{l}\text { Vasilyeva \& Ma } \\
2014\end{array}$ \\
\hline D. atlantica & $\begin{array}{l}\text { Chocolate } \\
\text { colored }\end{array}$ & $30-40$ & $4-6$ & Hyaline & $\begin{array}{l}\text { (6-)7-9(- } \\
10)\end{array}$ & - & $\begin{array}{l}\text { Vasiljeva \& } \\
\text { Stephenson. } 2009\end{array}$ \\
\hline D. bullata & $\begin{array}{l}\text { Light to dark } \\
\text { brown }\end{array}$ & $25-30$ & $5-7$ & $\begin{array}{l}\text { Slightly } \\
\text { yellowish }\end{array}$ & $7.5-9$ & - & $\begin{array}{l}\text { Vasilyeva \& Ma } \\
2014\end{array}$ \\
\hline D. caryae & Light brown & $28-33$ & $4-5$ & Hyaline & $5-7$ & - & $\begin{array}{l}\text { Vasiljeva \& } \\
\text { Stephenson. } 2009\end{array}$ \\
\hline D. decorticata & $\begin{array}{l}\text { Pallid-brown } \\
\text { or brown }\end{array}$ & $30-40$ & $4-6$ & Hyaline & $6-8$ & - & $\begin{array}{l}\text { Vasiljeva \& } \\
\text { Stephenson. } 2009\end{array}$ \\
\hline $\begin{array}{l}\text { D. } \\
\text { enteroxantha }\end{array}$ & $\begin{array}{l}\text { Brown or } \\
\text { black }\end{array}$ & $\begin{array}{l}18- \\
28.5\end{array}$ & $5-9$ & Subhyaline & $7-10$ & $1.5-2.5$ & Almeida et al. 2014 \\
\hline $\begin{array}{l}D . \\
\text { hypoxyloides }\end{array}$ & $\begin{array}{l}\text { Chocolate- } \\
\text { brown }\end{array}$ & $\begin{array}{l}(15- \\
) 20-25\end{array}$ & $4-6$ & Hyaline & $4-6$ & - & $\begin{array}{l}\text { Vasilyeva \& Ma } \\
2014\end{array}$ \\
\hline D. ilicina & Dark brown & $25-35$ & $4-6$ & Hyaline & $5-7$ & - & $\begin{array}{l}\text { Vasiljeva \& } \\
\text { Stephenson. } 2009\end{array}$ \\
\hline D. macounii & Dark brown & $25-30$ & $4-6$ & $\begin{array}{l}\text { Slightly } \\
\text { yellowish }\end{array}$ & $4-6$ & $0.7-1$ & $\begin{array}{l}\text { Vasilyeva \& Ma } \\
2014\end{array}$ \\
\hline D. spilomea & Black & $25-30$ & $4-6$ & - & $5-7$ & - & $\begin{array}{l}\text { Vasilyeva \& Ma } \\
2004\end{array}$ \\
\hline D. stigma & Brownish & $25-30$ & $5-7$ & Hyaline & $6-8$ & $1.5-2$ & $\begin{array}{l}\text { Vasilyeva \& Ma } \\
2014\end{array}$ \\
\hline D. stigmaoides & $\begin{array}{l}\text { Grey or dark- } \\
\text { grey }\end{array}$ & $20-30$ & $5-6$ & Hyaline & $4-6$ & - & $\begin{array}{l}\text { Vasiljeva \& } \\
\text { Stephenson. } 2009\end{array}$ \\
\hline $\begin{array}{l}\text { D. } \\
\text { subundulata }\end{array}$ & Dark brown & $35-40$ & $5-7$ & Yellowish & $7-9$ & $1.7-1.9$ & $\begin{array}{l}\text { Vasilyeva \& Ma } \\
2014\end{array}$ \\
\hline
\end{tabular}

The comparatively longer asci $(50-90 \mu \mathrm{m})$ of $D$. lijiangensis were observed to delineate from extant species such as $D$. decorticata $(30-40 \mu \mathrm{m})$, D. caryae $(28-33 \mu \mathrm{m})$, D. atlantica $(30-40 \mu \mathrm{m})$, D. ilicina $(25-35 \mu \mathrm{m})$, D. stigmaoides $(20-30 \mu \mathrm{m})$ (Vasiljeva \& Stephenson 2009), D. acerisrubrae (35-50 $\mu \mathrm{m})$ (Vasilyeva \& Stephenson 2014), D. Montana (30-35 $\mu \mathrm{m})$, D. rappazii (26-30 $\mu \mathrm{m})$ and $D$. subaffixa $(30-40 \mu \mathrm{m})$ (Vasilyeva \& Stephenson 2004). Our taxon shares similar morphological characteristics with the type species $D$. disciformis, but differs in having aseptate paraphyses whereas $D$. disciformis has septate paraphyses (Senanayake et al. 2015). D. disciformis phylogenetically differs from our new taxon in $2.47 \%$ (14/565) base pair differences present in ITS gene but $\beta$-tubulin sequence data were not available in GenBank for comparisons. $D$. virescens phylogenetically closely related to our taxon but, differs in $4.77 \%(27 / 565)$ base pair differences in ITS gene region and $\beta$-tubulin sequence data were not available in GenBank for comparisons. These two species exhibit distinct morphological differences in asci and ascospore characteristics whereas, asci and ascospores of $D$. virescens are 35-40 $\mu \mathrm{m}$ long and (10)12-14 $\mu \mathrm{m}$ long respectively (Vasiljeva \& Stephenson 2004).

\section{Acknowledgements}

We are grateful to Prof. Kevin D Hyde for the precise support to this work and Thailand Research Fund ("The future of specialist fungi in a changing climate: baseline data for generalist and specialist fungi associated with ants, Rhododendron species and Dracaena species DBG6080013" and "Impact of climate change on fungal diversity and biogeography in the Greater Mekong Sub-region RDG6130001”) for funding this research. We thank the Yunnan Provincial 
Human Resources and Social Security Bureau for a Yunnan Provincial Post-doctoral Grant to Fiona Worthy which financed the collecting expedition. We thank Udeni Jayalal, Nalin Wijayawardene and Monika Dayarathne for their precious help during this research. S.C. Karunarathna would like to thank CAS President's International Fellowship Initiative (PIFI) under the following grant: 2018PC0006 and the National Science Foundation of China (NSFC, project code 31750110478). Dhanushka Wanasinghe would like to thank CAS President's International Fellowship Initiative (PIFI) for funding his postdoctoral research (number 2019PC0008), the National Science Foundation of China and the Chinese Academy of Sciences for financial support under the following grants: 41761144055, 41771063 and Y4ZK111B01.

\section{References}

Acero FJ, González V, Sánchez-Ballesteros J, Rubio V et al. 2004 - Molecular phylogenetic studies on the Diatrypaceae based on rDNA-ITS sequences. Mycologia 96, 249-259.

Carter MV. 1991 - The status of Eutypa lata as a pathogen. Monograph. Phytopathological paper no. 32. Commonwealth Agricultural Bureau, International Mycological Institute, UK.

Dayarathne MC, Phookamsak R, Hyde KD, Manawasinghe IS et al. 2016 - Halodiatrype, a novel diatrypaceous genus from mangroves with $H$. salinicola and $H$. avicenniae spp. nov. Mycosphere 7(5), 612-627.

de Almeida DAC, Gusmão LFP, Miller AN. 2016 - Taxonomy and molecular phylogeny of Diatrypaceae (Ascomycota, Xylariales) species from the Brazilian semi-arid region, including four new species. Mycological Progress 15, 1-27.

de Errasti A, Novas MV, Carmarán CC. 2014 - Plant-fungal association in trees, insights into changes in ecological strategies of Peroneutypa scoparia (Diatrypaceae). Flora 209, 704 710.

Fries EM. 1849 - Summa vegetabilium scandinaviae sectio posterior 259-572 fungi and funguslike organisms in the South China Sea and their potential use in industry and pharmaceutical application. Malaysian Journal of Science 32 (SCS Sp Issue), 119-130.

Glass NL, Donaldson GC. 1995 - Development of primer sets designed for use with the PCR to amplify conserved genes from filamentous ascomycetes. Applied \& Environmental Microbiology 61, 1323-1330.

Glez-Peña D, Gómez-Blanco D, Reboiro-Jato M, Fdez-Riverola F et al. 2010 - ALTER: programoriented conversion of DNA and protein alignments. Nucleic Acids Research 38, 14-18.

Hall TA. 1999 - BioEdit: a user-friendly biological sequence alignment editor and analysis program for windows 95/98/NT. Nucleic Acids Symposium Series 41, 95-98.

Huelsenbeck JP, Ronquist FR. 2001 - MrBayes: Bayesian inference of 380 phylogenetics trees. Biometrics 17, 754-755.

Index Fungorum. 2019 - Available from: http://www.indexfungorum.org/Names/Names.asp (Accessed March 2019)

Jayasiri SC, Hyde KD, Ariyawansa HA, Bhat J et al. 2015 - The Faces of Fungi database: fungal names linked with morphology, phylogeny and human impacts. Fungal Diversity 74(1), 3-18.

Jeewon R, Hyde KD. 2016 - Establishing species boundaries and new taxa among fungi: recommendations to resolve taxonomic ambiguities. Mycosphere 7, 1669-1677.

Katoh K, Rozewicki J, Yamada KD. 2017 - MAFFT online service: multiple sequence alignment, interactive sequence choice and visualization. Briefings in Bioinformatics, bbx108.

Liu JK, Hyde KD, Gareth EBG, Ariyawansa HA et al. 2015 - Fungal diversity notes 1-110: taxonomic and phylogenetic contributions to fungal species. Fungal Diversity 72, 1-197.

Luo ZL, Hyde KD, Bhat DJ, Jeewon R et al. 2018 - Morphological and molecular taxonomy of novel species Pleurotheciaceae from freshwater habitats in Yunnan, China. Mycological progress, 17(5), 511-530.

Maharachchikumbura SSN, Hyde KD, Jones EBG, McKenzie EHC et al. 2015 - Towards a natural classification and backbone tree for Sordariomycetes. Fungal Diversity 72, 199-301. 
Maharachchikumbura SSN, Hyde KD, Jones EBG, McKenzie EHC et al. 2016 - Families of Sordariomycetes. Fungal Diversity 79, 1-317.

Mehrabi M, Hemmati R, Vasilyeva LN, Trouillas FP. 2015 - A new species and a new record of Diatrypaceae from Iran. Mycosphere 6, 60-68.

Mehrabi M, Hemmati R, Vasilyeva LN, Trouillas FP. 2016 - Diatrypella macrospora sp. nov. and new records of diatrypaceous fungi from Iran. Phytotaxa 252, 43-55.

Miller MA, Pfeiffer W, Schwartz T. 2010 - Creating the CIPRES Science Gateway for inference of large phylogenetic trees. In Gateway Computing Environments Workshop 2010 (GCE), New Orleans, Louisiana, November 2010, 1-8.

Nylander JAA. 2004 - MrModeltest 2.2: Program distributed by the author. Evolutionary Biology Centre, Uppsala University, Sweden.

Rambaut A. 2012 - FigTree, version 1.4.2. University of Edinburgh, Edinburgh.

Rannala B, Huelsenbeck JP, Yang Z, Nielsen R. 1998 - Taxon sampling and the accuracy of large phylogenies. Systematic Biology 47, 702-710.

Ronquist F, Huelsenbeck JP. 2003 - MrBayes 3: Bayesian phylogenetic inference under mixed models. Bioinformatics 19, 1572-1574.

Senanayake IC, Maharachchikumbura SSN, Hyde KD, Bhat JD et al. 2015 - Towards unraveling relationships in Xylariomycetidae (Sordariomycetes). Fungal Diversity 73(1), 73-144.

Senwanna C, Phookamsak R, Doilom M, Hyde KD et al. 2017 - Novel taxa of Diatrypaceae from Para rubber (Hevea brasiliensis) in northern Thailand; introducing a novel genus Allocryptovalsa. Mycosphere 8(10), 1835-1855.

Shang QJ, Hyde KD, Phookamsak R, Doilom M et al. 2017 - Diatrypella tectonae and Peroneutypa mackenziei spp. nov. (Diatrypaceae) from northern Thailand. Mycological progress 16(4), 463-476.

Stamatakis A. 2006 - RAxML-VI-HPC: maximum likelihood-based phylogenetic analyses with thousands of taxa and mixed models. Bioinformatics 22, 2688-2690.

Stamatakis A, Hoover P, Rougemont J. 2008 - A rapid bootstrap algorithm for the RAxML webservers. Systematic Biology 75, 758-771.

Tilak ST. 1964 - A new species of Diatrype from India, Mycopathologia 23(4), 249-251.

Trouillas FP, Gubler WD. 2004 - Identification and characterization of Eutypa leptoplaca, a new pathogen of grapevine in Northern California. Mycological Research 108, 1195-1204.

Trouillas FP, Úrbez-Torres JR, Gubler WD. 2010 - Diversity of diatrypaceous fungi associated with grapevine canker diseases in California. Mycologia 102, 319-336.

Trouillas FP, Pitt WM, Sosnowski MR, Huang R et al. 2011 - Taxonomy and DNA phylogeny of Diatrypaceae associated with Vitis vinifera and other woody plants in Australia. Fungal Diversity 49, 203-223.

Vasilyeva LN, Ma H. 2014 - Diatrypaceous fungi in north-eastern China. 1. Cryptosphaeria and Diatrype. Phytotaxa 186(5), 261-270.

Vasilyeva LN, Stephenson SL. 2004 - Pyrenomycetes of the Great Smoky Mountains National Park. I. Diatrype Fr. (Diatrypaceae). Fungal Diversity 17, 191-201.

Vasilyeva LN, Stephenson SL. 2009 - The genus Diatrype (Ascomycota, Diatrypaceae) in Arkansas and Texas (USA) Mycotaxon 107, 307-313.

Vasilyeva LN, Stephenson SL. 2014 - Notes on pyrenomycetous fungi in the Mountain Lake area of southwestern Virginia. Mycosphere 5(1), 218-227.

Wanasinghe DN, Phukhamsakda C, Hyde KD, Jeewon R et al. 2018 - Fungal diversity notes 709839: taxonomic and phylogenetic contributions to fungal taxa with an emphasis on fungi on Rosaceae. Fungal diversity, 89(1), 1-236.

White TJ, Bruns T, Lee J, Taylor SB. 1990 - Amplification and direct sequencing of fungal ribosomal RNA genes for phylogenetics. In: Innis MA, Gelfand DH, Sninsky JJ, White TJ (eds), PCR protocols: a guide to methods and applications 315-322. Academic Press, San Diego, California, USA. 
Wijayawardene NN, Hyde KD, Rajeshkumar KC, Hawksworth DL et al. 2017 - Notes for genera: Ascomycota. Fungal diversity 86(1), 1-94.

Wijayawardene NN, Hyde KD, Lumbsch HT, Liu JK, Maharachchikumbura SS et al. 2018 Outline of Ascomycota. Fungal Diversity 88(1), 167-263.

Zhaxybayeva O, Gogarten JP. 2002 - Bootstrap, Bayesian probability and maximum likelihood mapping: exploring new tools for comparative genome analysis. BMC Genomics 3(1), 4. 